Vladimir M. Chekmarev

senior researcher of the Scientific Research Institute of

Theory of Architecture and Town-Planning-

the branch of the "CNIIP of the Ministry of Construction of Russia»

e-mail:wchekmarev@yandex.ru

Moscow, Russia

Orcid 0000-0001-6557-3035

ResearcherID AAB-8263-2020

DOI: $10.36340 / 2071-6818-2019-15-4-161-171$

\title{
HISTORY OF AHTYRKI MANOR COMPLEX FORMATION
}

Summary. The article concerns the formation of the manor complex of Akhtyrka in the context of the development of Russian estate culture of the early XIX century. Based on textual and graphic materials, the author makes an attempt to clarify the features of the planning structure and the figurative and artistic originality of the estate, formed in the 1820s. The new manor complex was located on the picturesque steep slope of the left bank of the river Vorya, that was specially blocked to create very vast ponds, effectively edged with landscape and regular parts of the park. All elements of manor buildings corresponded to the style of late Moscow classicism, in particular, the architectural work of D. Gilardi. The central elevated part of the palace was crowned with a dome, and its garden façade was accented by a semi-secular terrace located in the center. Its northern facade was accented by a six-columned portico with a pediment decorated with the stucco coat of arms of the Princes Trubetskoy. On the north side, an extensive front yard was approaching the building, which in plan was close to the shape of a square. In its central part there was a pool with a fountain, around which roses and many other no less bright colors grew along symmetrically laid paths. The formation of the park fully met the general planning plan developed by one of the outstanding masters of landscape gardening art. On the lithographs dated $1^{\text {st }}$ half of the XIX century by an unknown artist called "View of the village of Akhtyrki, owned by Prince Ivan Nikolaevich Trubetskoy. From Moscow - 60, and from Khotkovo in 3 versts " this newly created complex is represented by picturesque ponds. Here we find their asymmetric shores, elegantly drawn, the bridge, the vast landscape park, the alleys and the very long volume of the main manor house, which rises spectacularly over the entire surrounding area. In front of the southern facade of the main house, a vast meadow was built on the relief smoothly lowering to the ponds. Near the building itself, birch trees flanked it, and from the east and west there were straight avenues planted only with lindens. At the coastline, we notice asymmetrically planted cypress trees together with shrubs. In 1924, the manor house burned down, which entailed the complete liquidation of the estate complex.

Keywords: Russian estate culture, 1820s, formation of the estate, main house, outbuilding, park environment. 


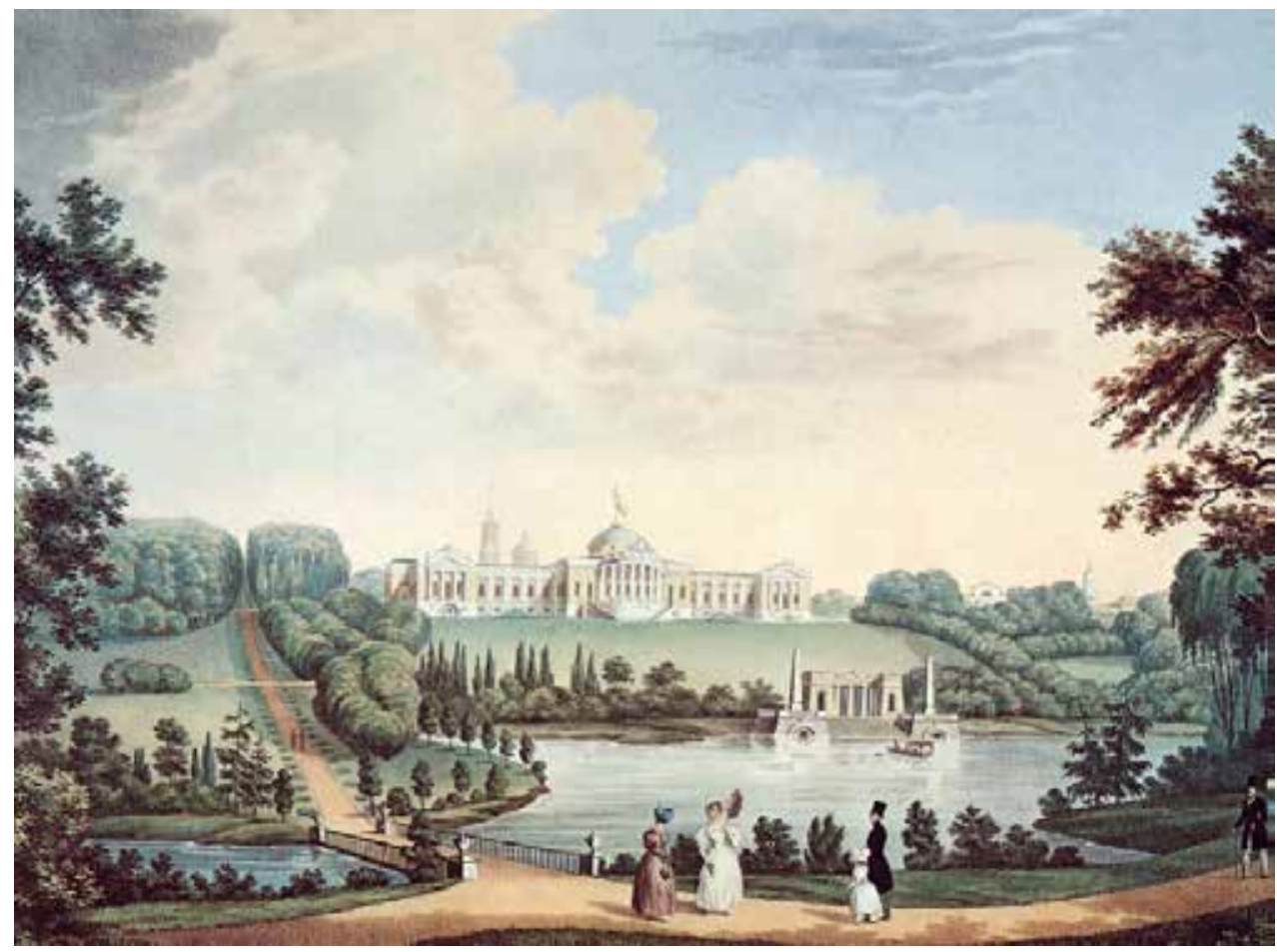

State Historic Museum. "View of the village Ahtirka property of Ivan Nikolaevich Trubetskoy.

From Moscow - 60, from Khotkovo 3 versti». 1820 s

Akhtyrka estate complex has not yet attracted the attention of researchers. The purpose of this article is to identify the planning as well as figurative and artistic identity of this unique ensemble characteristic for Russian classicism at the beginning of the 19th century.

The first mention of the current village of Akhtyrka dates back to the boundary spiritual certificate of 1504, where it is listed as «the village of Dudkino». However, in the middle of the XV century. This land was known as the «wasteland of Dudkino» of the Inobozhsky camp of Dmitrovsky district, which belonged to the Trinity-Sergius Monastery.

In 1694 the village belonged to Ivan Andreevich Panin and already from his heirs passed to their relative Vasily Nikitich Tatishchev, and from him in 1734 into the possession of Prince I.Y. Trubetskoy, who retained it until 1744 . $^{1}$

After his death, the estate was inherited by his son, Prince Nikolai Ivanovich Trubetskoy. The renaming of Dudkino to Akhtyrka and the construction of a wooden church in it in honor of the Akhtyr Icon of the Mother of God should be associated with him. ${ }^{2}$ Until the end of the 1810 s the Trubetskoys lived in a relatively small estate with a wooden manor-house oriented to the park, apparently built under the Panins.

1. RGADA. F.1209. Op. 736. D. 15094. L. 2.

2. CIAM. F. 203. Op. 206. D. 406. L. 1- 22. 
In the 1820s Ivan Nikolaevich Trubetskoy proceeded to form a highly developed manor complex in Akhtyrka in accordance with a project developed by architect A.S. Kutepov. There is every reason to believe that the spouse of the prince, N.S. Trubetskaya, was directly involved in its creation. She personally oversaw the construction of the palace, the church, and the breakdown of the park with a pond. ${ }^{3}$

This new Akhtyr manor complex was located on the picturesque steep slope of the left bank of the river Vorya, which was specially blocked to create very vast ponds, effectively edged with landscape and regular parts of the park. The main manor house itself, strongly stretched along its longitudinal axis, a wooden one-story building on a high white stone basement, was also located on a hill, somewhat west of the old manor with its main house and wooden church.

From the side of the spacious courtyard it was flanked by the mansions of the Kitchen and the Guest wing. Absolutely all these new manor buildings corresponded to the style of the late Moscow classicism, in particular, the architectural work of D. Gilardi.

On the lithographs of the 1st half of the XIX century by an unknown artist called "View of the village of Akhtyrki, owned by Prince Ivan Nikolaevich Trubetskoy. From Moscow - 60, and from Khotkovo in 3 versts» this newly created complex is represented from the side of picturesque ponds. Here we find their asymmetric shores, elegantly drawn, the bridge, the vast landscape park, the alleys and the very long volume of the main manor house, which rises spectacularly over the entire surrounding area. ${ }^{4}$

The central elevated part of the palace was crowned with a dome, and its garden façade was accented by a semi-circle terrace located in the center. It was supplemented by a balcony and a white stone ramp leading to the park. The wide-spread glazed wingstransitions of the main volume of the building approached the symmetrically located one-story wings. Behind the main manor volume, one can also see the stone church, built a little later as an integral part of this vast manor complex. And at the very pond we notice the boat pier, which was a very peculiar structure, decorated with paired obelisks.

In front of the southern facade of the main house, a vast meadow was built on the relief smoothly lowering to the ponds. Near the building itself, birch trees flanked it, and from the east and west there were straight avenues planted only with lindens. At the coastline, we notice asymmetrically planted cypress trees together with shrubs.

It should be noted that during the formation of the landscape parts of the park, the previously forested area was almost completely eliminated, while the tall, deciduous and coniferous trees corresponding to the general composition were preserved. Among the new plantings, a wide variety of lilac, acacia, hawthorn and other ornamental shrubs were actively used.

3. Tikhomirov N.Ya. Arkhitektura podmoskovnih usadeb (Architecture of Moscow district estates. Moscow, 1955. P. 267 -268). Pamyatniki arkhitekturi Moskovskoy oblasti. (Architectue of Moscow district). M., 1975. V. 1. P. 155).

4. GIM. Engraving «View of Ahtirka village of prince Ivan Nikolaevich Trubetskoy. From Moscow - 60, from Khotkovo 3 versti». 1820s. 


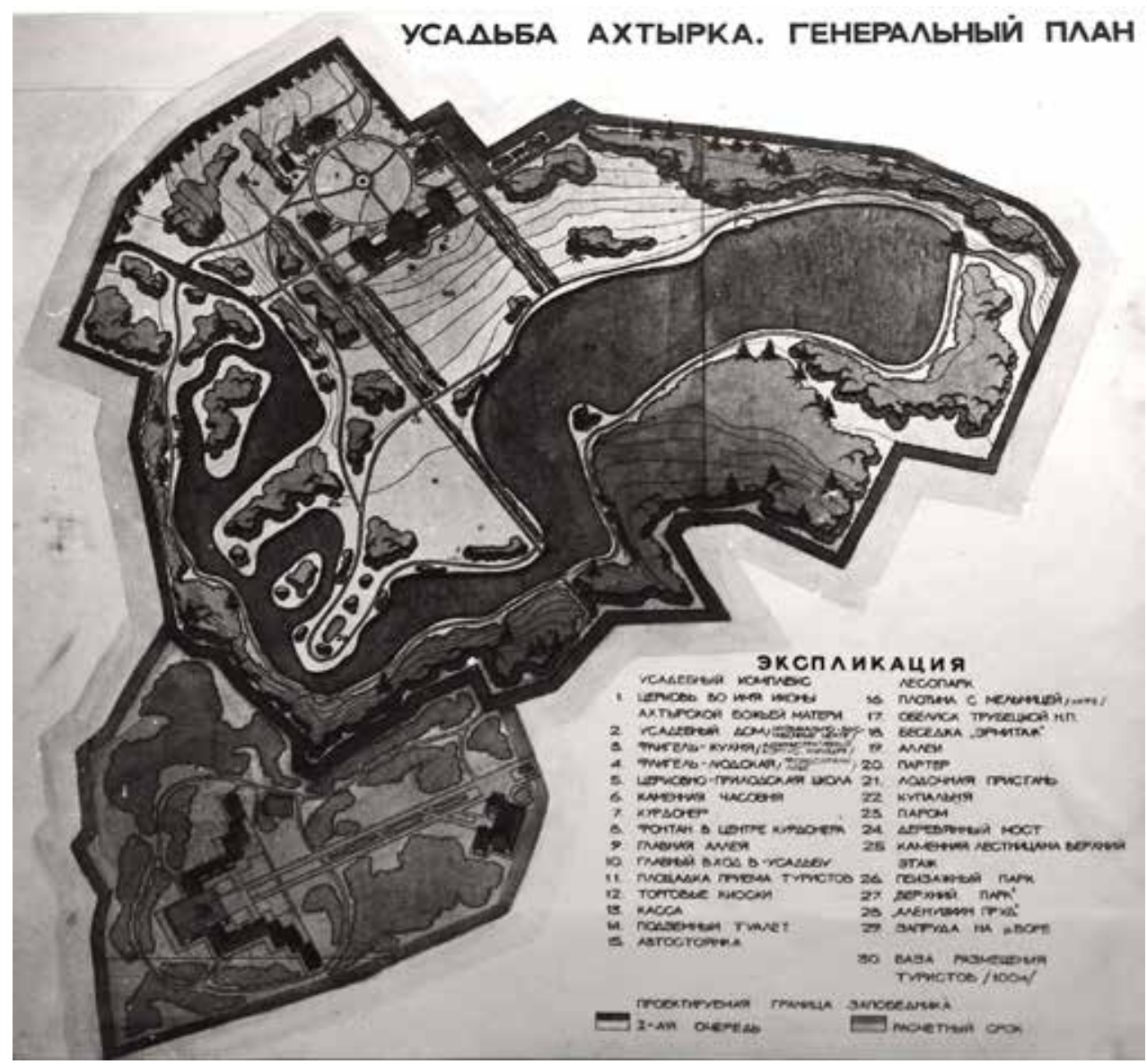

«Ahtirka estate. General planning». Spezproyektrestavratsia. 1978. (Abrantsevo museum archive)

The formation of all the park parts fully corresponded to the general planning, undoubtedly developed by one of the outstanding masters of landscape gardening. This is also evidenced by the finely thought out transformation of the pristine relief, which made it possible to further emphasize the special landscape expressiveness of this highly rugged terrain.

The Trubetskoys owned Akhtyrka until 1879, with its last owners being the chairman of the Russian Musical Society, N.P. Trubetskoy and his brother P.P. Trubetskoy. In the same year, they were forced to sell this property urgently in order to redeem their brother, an avid gambler, from a debt prison. ${ }^{5}$

As a result, in 1883, Akhtyrka was acquired by Ivan Mikhailovich Matveev, the magistrate of Moscow - a great connoisseur of fine art, music, an amateur flower grower. It was under him that the estate ensemble was brought into excellent condition.

5. Ganishin D.S. Ahnirka. Zapiski kraeveda (Ahnirka. Notes of a local historian) // Panorama iskusstv. Moscow, 1981. № 4. P. 414. 
Preserved photos of the turn of the XIX-XX centuries allow us to clarify the original layout of the estate and the compositional solution of the facades of its main volumes.

Thus, the central part of the northern facade of the main house was marked by a six-column portico with a pediment decorated with the stucco coat of arms of the Trubetskoy princes. As it can be seen in the photos, the walls of the main house were decorated with square rust. The compositional interaction of the paired wings with its increased volume was carried out thanks to the column porticos. And as contemporaries clarified, the exterior walls of the main house, its wings and kitchen were painted in pale yellow, and the columns and decor were whitewashed, which further emphasized the sophistication of the entire composition and revealed the general style of the design concept, which is very characteristic of late Moscow classicism. The original layout of the building has also changed, as evidenced by the small extensions with independent entrances located on the North side of the building.

On the North side, the building was approached by a large front yard, which was close to the shape of a square in plan. In the Central part of it was a pool with a fountain, around which and along the symmetrically laid paths grew roses and many other equally bright colors.

It was the front yard that contained the ring road that provided access to the main house, church, and other manor buildings. It also offered panoramic views of the ponds, the Upper and Lower landscape parks, and the picturesque surroundings of the estate. A path led from the South facade of the main house to the Upper Park. It was bordered only by spruces and led to a two-story arbor «Hermitage», which ended with a spire with a weather vane.

Matveev's heirs owned Akhtyrka until 1918, when the entire estate complex was nationalized and soon adapted for an orphanage. In 1924, the main manor house burned down, which led to a rapid it's elimination together with all economic and service buildings. The dam collapsed, as a result of which the vast reservoirs built in the $1820 \mathrm{~s}$ on the dammed river Vorya immediately disappeared. Soon trees and shrubs were cut down in the landscape and regular parts of the Park, greenhouses and greenhouses were broken. By the 1930s, the Park space that had been previously opened in front of the southern facade of the main house gradually descending to the river and the water area of the ponds have completely overgrown, completely losing their former figurative expressiveness.

\section{REFERENCES}

1. García Martín, Fernando Miguel. 2019. "Los valores de compacidad y densidad en los tejidos residenciales de la periferia de las ciudades intermedias españolas a lo largo del siglo XX », ACE: Architecture, City and Environment, vol. 14, no. 40, pp. 11-34. doi: 10.5821/ace.14.40.5690 (in Spanish)

2. Cilísia Ornelas, J. Miranda Guedes, Fernanda Sousa \& I. Breda-Vázquez. 2020. "Supporting Residential Built Heritage Rehabilitation through an Integrated Assessment", International 
Journal of Architectural Heritage, vol.14, no.1, doi: 10.1080/15583058.2020.1712496 (in English)

3. Ganishin D.S. 1981. "Ahnirka. Zapiski kraeveda" ["Ahnirka. Notes of a local historian"], Panorama iskusstv. Moscow, no. 4.pp. 384 - 418. (in Russian)

4. Karolina Ogrodnik. 2019. "Indicators of the compact city concept - necessary data and the possibility of application", The Journal "Architecture Civil Engineering Environment "ACEE, no.4, vol.12, pp. 23-36 doi:10.21307/ACEE-2019-049 (in English)

5. Liu Yang, Koen H. van Dam, Arnab Majumdar, Bani Anvari, Washington Y. Ochieng, Lufeng Zhang. 2019. "Integrated design of transport infrastructure and public spaces considering human behavior: A review of state-of-the-art methods and tools", Frontiers of Architectural Research, vol.8, no4, pp. 429-453, doi: 10.1016/j.foar.2019.08.003. (in English)

6. Pamyatniki arkhitekturi Moskovskoy oblasti. [Architectue of Moscow district]. 1975. Moscow., vol. 1. p. 155. (in Russian)

7. Shevchenko, N. Yu. 2010. Russkaya sel'skaya usad'ba (1860-1917) [Russian rural estate (1860s-1917)]. PhD Thesis Abstract. Saratov (in Russian)

8. Tikhomirov N.Ya. 1955. Arkhitektura podmoskovnih usadeb [Architecture of Moscow district estates], Moscow, pp. 267 - 268. (in Russian)

9. Vittorio Amadio Guidi. 2019. "Fragments of Natural Landscape", ArcHistoR Architettura Storia Restauro - Architecture History Restoration, no. 4, pp. 108-121. doi:108-121 DOI 10.14633/AHR098 (in Italian) 
Владимир Михайлович Чекмарёв доктор архитектуры ведущий научный сотрудник отдела истории архитектуры и градостроительства Нового времени Филиала ФГБУ «ЦНИИП МИНСТРОЯ России» Научно-исследовательский институт теории и истории архитектуры и градостроительства e-mail:wchekmarev@yandex.ru Москва, Россия

Orcid 0000-0001-6557-3035 ResearcherID AAB-8263-2020

DOI: $10.36340 / 2071-6818-2019-15-4-161-171$

\section{История формирования усадебного комплекса Ахтырки}

аннотация. В статье рассматривается становление усадебного комплекса Ахтырки в контексте развития русской усадебной культуры начала XIX века. На основе текстовых и графических материалов автор делает попытку прояснить особенности планировочной структуры и образно-художественного своеобразия усадьбы, сформировавшейся в 1820-е годы. Новый усадебный комплекс расположили на живописном обрывистом склоне левого берега р. Вори, которую специально перегородили для создания весьма обширных прудов, эффектно окаймлявшихся пейзажными и регулярными частями парка. Все элементы усадебных строений соответствовали стилю позднего московского классицизма, в частности, архитектурному творчеству Д. Жилярди. Центральная повышенная часть дворца была увенчана куполом, а садовый ее фасад акцентирован расположенной в центре террасой-полуротондой. Северный его фасад был акцентирован шестиколонным портиком с фронтоном, украшенным лепным гербом князей Трубецких. С северной стороны к зданию подступал обширный парадный двор, который в плане был близок к форме квадрата. В центральной его части располагался бассейн с фонтаном, вокруг которого и вдоль симметрично проложенных дорожек росли розы и множество других не менее ярких цветов. Формирование парка в полной мере отвечало общему планировочному замыслу, разработанном одним из незаурядных мастеров садово-паркового искусства.

Ключевые слова: Русская усадебная культура, 1820-е гг., формирование усадебного комплекса, усадебный дом, перестройка, парковая среда.

В специальной литературе усадебный комплекс Ахтырки еще не привлекал к себе внимание исследователей. Целью данной статьи является выявление планировочного и образно-художественного своеобразия этого уникального ансамбля, отвечающего характерным особенностям русского классицизма начала XIX в. 
Первые упоминания о нынешнем селе Ахтырка восходят к межевой духовной грамоте 1504 г., где оно значится как «сельцо Дудкино». Однако и в середине XV в. это владение было известно, как «пустошь Дудкино» Инобожского стана Дмитровского уезда, принадлежавшее Троице-Сергиеву монастырю.

В 1694 г. село принадлежало Ивану Андреевичу Панину и уже от его наследников перешло к их родственнику Василию Никитичу Татищеву, а от него в 1734 г. отошло во владение князя И.Ю. Трубецкого, который сохранял его за собой вплоть до 1744 г. ${ }^{1}$

После смерти отца имение унаследовал его сын, князь Николай Иванович Трубецкой. С ним и следует связывать переименование Дудкино в Ахтырку и строительство в ней деревянной церкви в честь Ахтырской иконы Божией Матери. ${ }^{2}$ Вплоть до конца 1810-х гг. Трубецкие жили в сравнительно небольшой усадьбе с ориентированным в парк деревянным господским домом, выстроенным, видимо, еще при Паниных.

В 1820-е гг. Иван Николаевич Трубецкой приступил к формированию в Ахтырке весьма развитого усадебного комплекса в соответствии с проектом, разработанным архитектором А.С. Кутеповым. Есть все основания полагать, что непосредственным его созданием занималась супруга князя - Н.С. Трубецкая, которая лично курировала строительство дворца и церкви, а также разбивку парка с прудом. ${ }^{3}$

Этот новый ахтырский усадебный комплекс расположили на живописном обрывистом склоне левого берега р. Вори, которую специально перегородили для создания весьма обширных прудов, эффектно окаймлявшихся пейзажными и регулярными частями парка. Сам же сильно растянутый по продольной своей оси главный усадебный дом, представлявший собой деревянный одноэтажный объем на высоком белокаменном цоколе, размещался также на возвышенности, несколько западнее старой усадьбы с ее главным домом и деревянной церковью. Со стороны просторного двора его фланкировали объемы кухни и гостевого флигеля. Абсолютно все эти новые усадебные постройки вполне соответствовали стилю позднего московского классицизма, в частности, архитектурному творчеству Д. Жилярди.

На датированной 1-й половиной XIX в. литографии неизвестного художника под названием «Вид села Ахтырки, принадлежащего князю Ивану Николаевичу Трубецкому. От Москвы - 60, а от Хотьково в 3-х верстах» этот вновь созданный комплекс представлен со стороны живописных прудов. Здесь находим и изысканно прорисованные их асимметричные берега, и мостик, и обширный пейзажный

1. РГАДА. Ф.1209. Оп. 736. Д. 15094. Л. 2.

2. ЦИАМ. Ф. 203. Оп. 206. Д. 406.Л. 1- 22.

3. Тихомиров Н.Я. Архитектура подмосковных усадеб. М., 1955. С. 267 - 268; Памятники архитектуры Московской области. М., 1975. Т. 1. С. 155. 
парк, и аллеи и сильно протяженный объем главного усадебного дома, эффектно возвышающегося над всей окружающей местностью. ${ }^{4}$

Центральная повышенная часть дворца была увенчана куполом, а садовый ее фасад акцентирован расположенной в центре террасой-полуротондой. Она дополнялась балконом и белокаменным сходом, ведущим в парк. Широко раскинувшиеся остекленные крылья-переходы основного объема здания подступали к симметрично расположенным одноэтажным флигелям. За главным усадебным объемом просматривается и каменная церковь, выстроенная чуть позже, но в качестве составного элемента этого обширного усадебного комплекса. А на самом пруду замечаем и лодочную пристань, представлявшую собой весьма своеобразное сооружение, украшенное пар-ными обелисками. Перед южным фасадом главного дома был устроен на плавно понижающемся к прудам рельефе обширный луг. Вблизи самого здания его фланкировали березы, а с востока и запада - прямые аллеи, обсаженные только липами. У береговой черты замечаем и асимметрично высаженные кипарисы совместно с кустарниками.

Следует отметить, что при формировании пейзажных частей парка прежде находившийся здесь лесной массив практически полностью ликвидировался с сохранением отвечавших общей композиции высокорослых лиственных и хвойных деревьев. Среди новых посадок активно использовали самые различные сорта сирени, акации, боярышника и других декоративных кустарников.

Формирование всех парковых частей в полной мере отвечало общему планировочному замыслу, несомненно, разработанному одним из незаурядных мастеров садово-паркового искусства. Об этом свидетельствует тонко продуманная трансформация первозданного рельефа, позволявшая еще более подчеркнуть особую пейзажную выразительность этой сильно пересеченной местности.

Трубецкие владели Ахтыркой вплоть до 1879 г., причем последними ее владельцами были председатель Русского музыкального общества Н.П. Трубецкой и его брат П.П. Трубецкой. В том же году они были вынуждены срочно продать это свое имение чтобы выкупить из долговой тюрьмы родного брата - заядлого картежника. $^{5}$

В результате в 1883 г. Ахтырку приобрел Иван Михайлович Матвеев, мировой судья Москвы - большой знаток изобразительного искусства, музыки, цветовод-любитель. Именно при нем усадебный ансамбль был приведен в отличное состояние.

Сохранившиеся фотографии рубежа XIX - XX вв. позволяют прояснить исходную планировку усадьбы и композиционное решение фасадов основных его объемов.

Так, центральная часть северного фасада главного дома была отмечена шестиколонным портиком с фронтоном, украшенным лепным гербом князей Трубецких.

4. ГИМ. Гравюра «Вид села Ахтырки, принадлежащего князю Ивану Николаевичу Трубецкому. От Москвы - 60, а от Хотьково в 3-х верстах». 1820-е гг.

5. Ганешин Д.С. Ахтырка. Записки краеведа // Панорама искусств. М., 1981. № 4. С. 414. 
Как видно на фотографиях, стены главного дома декорировались квадровым рустом. Композиционное взаимодействие парных флигелей с повышенным его объемом осуществлялось благодаря колонным портикам. Как отмечали современники, наружные стены главного дома, его флигелей и кухни были окрашены в бледно-желтый цвет, а колонны и декор были выбелены, что еще более подчеркивало изысканность всей композиции и выявляло общую стилевую направленность проектного замысла, весьма характерного для позднего московского классицизма. Видоизменилась и пер-воначальная планировка здания, о чем наглядно свидетельствуют размещенные со стороны его северного фасада небольшие пристройки с самостоятельными входами.

С северной стороны к зданию подступал обширный парадный двор, который в плане был близок к форме квадрата. В центральной его части располагался бассейн с фонтаном, вокруг которого и вдоль симметрично проложенных дорожек росли розы и множество других не менее ярких цветов.

Именно парадный двор содержал кольцевую дорогу, обеспечивавшую подъезд к главному дому, церкви и другим усадебным постройкам. Отсюда также открывались панорамные виды на пруды, Верхний и Нижний пейзажные парки, живописные окрестности усадьбы. От южного фасада главного дома отходила дорожка в сторону Верхнего парка. Она была обсажена одними только елями и приводила к двухэтажной беседке «Эрмитаж», которая завершалась шпилем с флюгером.

У наследников Матвеева Ахтырка находилась в собственности вплоть до 1918 г., когда весь усадебный комплекс был национализирован и вскоре приспособлен под детский дом.

В 1924 г. главный усадебный дом сгорел, что повлекло за собой довольно скорую ликвидацию композиционно связанных с ним хозяйственных и служебных строений. Затем разрушилась плотина, в результате чего обширные водоемы, устроенные на запруженной р. Воре еще в 1820-е гг., сразу исчезли. А вскоре были вырублены деревья и кустарники в пейзажных и регулярных частях парка, сломаны оранжереи и парники. К 1930-м гг. прежде открытое перед южным фасадом главного дома обширное плавно понижающееся к р. Воре парковое пространство и сама акватория прудов окончательно заросли, полностью утратив прежнюю образную свою вырази-тельность.

\section{БИБЛИОГРАФИЯ}

1. Тихомиров Н.Я. Архитектура подмосковных усадеб. М., 1955. С. 267 - 268.

2. Памятники архитектуры Московской области. М., 1975. Т. 1. С. 155.

3. Ганешин Д.С. Ахтырка. Записки краеведа // Панорама искусств. М., 1981. № 4. С. $384-418$.

4. García Martín, Fernando Miguel. 2019. "Los valores de compacidad y densidad en los tejidos residenciales de la periferia de las ciudades intermedias españolas a lo largo del siglo XX », ACE: Architecture, City and Environment, vol. 14, no. 40, pp. 11-34. doi: 10.5821/ace.14.40.5690 (in Spanish) 
5. Vittorio Amadio Guidi. 2019. "Fragments of Natural Landscape", ArcHistoR Architettura Storia Restauro - Architecture History Restoration, no. 4, pp. 108-121. doi:108-121 DOI 10.14633/ AHR098 (in Italian)

6. Karolina Ogrodnik. 2019. "Indicators of the compact city concept - necessary data and the possibility of application", The Journal "Architecture Civil Engineering Environment "ACEE, no.4, vol.12, pp. 23-36 doi:10.21307/ACEE-2019-049

7. Liu Yang, Koen H. van Dam, Arnab Majumdar, Bani Anvari, Washington Y. Ochieng, Lufeng Zhang. 2019. "Integrated design of transport infrastructure and public spaces considering human behavior: A review of state-of-the-art methods and tools", Frontiers of Architectural Research, vol.8, no4, pp. 429-453, doi: 10.1016/j.foar.2019.08.003. (in English)

8. Cilísia Ornelas, J. Miranda Guedes, Fernanda Sousa \& I. Breda-Vázquez. 2020. "Supporting Residential Built Heritage Rehabilitation through an Integrated Assessment", International Journal of Architectural Heritage, vol.14, no.1, doi: 10.1080/15583058.2020.1712496 (in English)

9. Надежда Юрьевна Шевченко. Русская сельская усадьба (1860-е-1917 гг.): диссертация ... кандидата исторических наук: 07.00.02. - Саратов, 2010. - 262 с.: ил. [Место защиты: ГОУ ВПО Саратовский государственный университет им. Н. Г. Чернышевского]. - Саратов, 2010. 